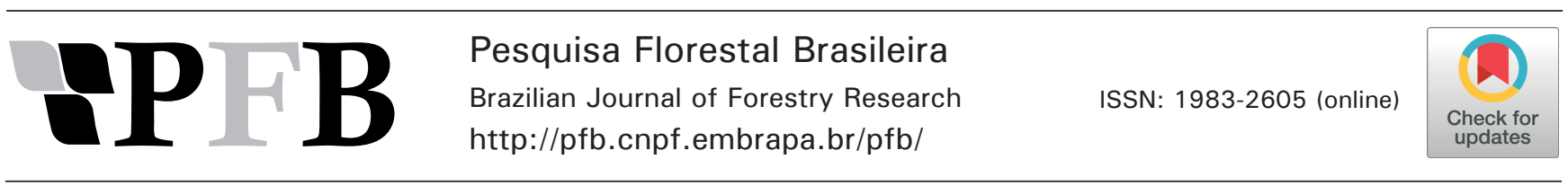

\title{
Tolerance of jenipapo seeds to cryoprotectants and thawing after immersion in liquid nitrogen
}

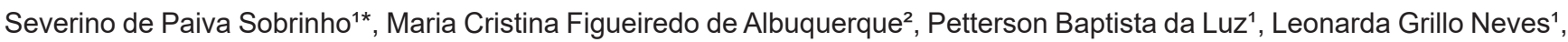 \\ Elisangela Clarete Camili²
}

${ }^{1}$ Universidade do Estado de Mato Grosso, Av. São João, S/N, CP. 118, CEP 78200-970, Cáceres, MT, Brasil

${ }^{2}$ Universidade Federal do Mato Grosso, Av. Fernando Correia da Costa, 2367, CEP 78060-900, Cuiabá, MT, Brasil

\section{"Corresponding author: \\ paivasevero@unemat.br \\ Index terms: \\ Genipa americana \\ Germplasm conservation \\ Seed preservation}

Termos para indexação:

Genipa americana

Conservação de germoplasma

Conservação de sementes

Received in 05/02/2016

Accepted in 17/11/2017

Published in 29/12/2017

doi: 10.4336/2017.pfb.37.92.1145

\begin{abstract}
The objective of this study was to evaluate the effects of two cryoprotectants followed by thawing on the physiological potential of Genipa americana L. seeds. Two experiments testing 12 treatments were conducted, one for each cryoprotectant, both in a factorial scheme of $6 \times 2$ (cryoprotectant concentrations $\times$ thawing methods). We tested $0,5,10,15,20$, and $25 \%$ for dimethyl sulfoxide, and $0,0.25,0.5,0.75,1.0$, and $1.25 \mathrm{M}$ for sucrose. The thawing methods were fast $\left(38^{\circ} \mathrm{C}\right.$ for $\left.30 \mathrm{~min}\right)$ and slow $(25$ ${ }^{\circ} \mathrm{C}$ for $4 \mathrm{~h}$ ). The seeds were immersed in the cryoprotectant solution for $3 \mathrm{~h}$, stored for $120 \mathrm{~h}$, and then thawed. The seeds were then sown in substrate (sand and vermiculite, 1:1). Emergence percentage along with speed index, length, fresh and dry matter mass of seedlings were evaluated. Dimethyl sulfoxide and sucrose can be used as cryoprotectants in G. americana seeds. Thawing should be slow when treating seeds with dimethyl sulfoxide.
\end{abstract}

\section{Tolerância de sementes de jenipapo a crioprotetores e ao descongelamento após imersão em nitrogênio líquido}

\begin{abstract}
Resumo - Objetivou-se neste trabalho avaliar os efeitos de dois crioprotetores e métodos de descongelamento sobre o potencial fisiológico de sementes de Genipa americana L. Foram realizados dois experimentos, um para cada crioprotetor, sendo testados 12 tratamentos para cada um, ambos em esquema fatorial 6 x 2 (concentrações de crioprotetor x modos de descongelamento). As concentrações de dimetilsulfóxido foram: $0,5,10,15,20$ e $25 \%$ e as de sacarose: $0,0,25,0,5,0,75,1,0$ e $1,25 \mathrm{M}$. Os modos de descongelamento foram o rápido $\left(38^{\circ} \mathrm{C}\right.$ em $\left.30 \mathrm{~min}\right)$ e o lento $\left(25^{\circ} \mathrm{C} \mathrm{em}\right.$ $4 \mathrm{~h}$ ). As sementes foram imersas por $3 \mathrm{~h}$ em solução crioprotetora e em seguida armazenadas por $120 \mathrm{~h}$, sendo posteriormente descongeladas. Em seguida, foram semeadas em substrato (areia + vermiculita 1:1). Avaliou-se a porcentagem e o índice de velocidade de emergência, comprimento e massa de matéria fresca e seca de plântulas. O dimetilsulfóxido e a sacarose podem ser utilizados como crioprotetor em sementes de G. americana. O descongelamento deve ser lento para as sementes tratadas com dimetilsulfóxido.
\end{abstract}

\section{Introduction}

The loss of native forest areas in Cerrado biome is jeopardizing various plant species, which have drug, timber, and food potential, such as jenipapo (Genipa americana L.). It is therefore critical to conduct studies focused on this germplasm for ex situ or in situ preservation.

The ex situ preservation shows some advantages compared to in situ, such as reduced need for space, lower 
expenses and labor costs, easier germplasm exchange, and reduced genetic erosion (Engelmann, 1991). Seed preservation is the easiest, most common and efficient means of ex situ preservation, since the seeds ensure genetic variability, are easily collected, and occupy small spaces (Li \& Pritchard, 2009; Goldfarb et al., 2010; Pence, 2010).

Cryopreservation proved to be very efficient and inexpensive. According to Pita et al. (1998) and Tresena et al. (2009), cryopreservation is a technique that allows preservation of germplasm for several years under ultralow temperatures, usually $-196{ }^{\circ} \mathrm{C}$. The motion of molecules at this temperature is greatly reduced and there is no liquid phase in the cell. The risk of biological material loss is smaller and costs are lower than those for in vitro preservation, for example. When feasible, seed cryopreservation of a particular species at $-196{ }^{\circ} \mathrm{C}$ can provide indefinite storage longevity, because seed metabolic activity is minimal at temperatures below $-130{ }^{\circ} \mathrm{C}$, and can thus be considered negligible (Fonseca et al., 2012).

Cryopreservation in liquid nitrogen is considered a suitable method for long-term preservation (Vasanth \& Vivier, 2011; Padro et al., 2012); however, cryoprotectants promote better seed preservation for many species when this storage method is used. Among the compounds normally used for this purpose are sucrose, glycerol, dimethyl sulfoxide, and methanol (Benson, 2008).

The cryoprotectants protect the cells, allowing them to reach a lethal minimum volume, and make it possible to decrease freezing temperature (Gallo, 2015). Tao \& Li (1986) classified commonly used compounds according to their capacity to penetrate the cell wall: (1) compounds unable to penetrate the cell wall (high molecular weight polymers-PEG ${ }_{6000}$ and PVP-polysaccharides, and proteins); (2) those able to penetrate the cell wall only (oligosaccharides, mannitol, amino acids and low molecular weight polymers- $\mathrm{PEG}_{1000}$ ); and (3) those able to penetrate the cell wall and membrane (dimethyl sulfoxide and glycerol).

Another important factor in cryopreservation is the thawing method. Usually, when seeds are thawed quickly, the risk of ice crystal formation by refreezing during this process is lower, allowing better preservation of the physiological characteristics (Molina et al., 2006).

The objective of the present study was to evaluate the cryoprotectants dimethyl sulfoxide and sucrose in cryostorage along with the fast and slow thawing methods on the physiological potential of $G$. americana seeds.

\section{Material and methods}

Genipa americana ripe fruits were collected on the ground after natural fall from 10 trees in Caceres, Mato Grosso State, Brazil (16 $\left.03^{\prime} 15^{\prime \prime S}, 57^{\circ} 40^{\prime} 04^{\prime \prime} \mathrm{W}\right)$, in November 2013. In the laboratory, the fruits were manually opened and the seeds were extracted. Subsequently, the seeds were placed on a sieve and rubbed by hand under running water to completely remove the mesocarp. The seeds were mixed to form a single lot and dried naturally on paper towels on the laboratory bench for $120 \mathrm{~h}$, at an average temperature of $25^{\circ} \mathrm{C}$ and relative humidity of $46 \%$. Two subsamples of 25 seeds were taken before and after drying to evaluate water content using the oven method at $105 \pm 3{ }^{\circ} \mathrm{C}$ for $24 \mathrm{~h}$ (Brasil, 2009).

The cryoprotectants dimethyl sulfoxide (DMSO) and sucrose $\left(\mathrm{C}_{12} \mathrm{H}_{22} \mathrm{O}_{11}\right)$ were evaluated separately because of their specific characteristics and the different concentration used.

G. americana seeds had $38.7 \%$ water content on wet basis (wb) just after collection, $11.3 \% \mathrm{wb}$ after the natural drying period and $84 \%$ of emergence.

The treatments of liquid nitrogen immersion were distributed in a completely randomized design, in a $6 \times 2$ factorial scheme (cryoprotectant concentrations $\times$ thawing methods), totalizing 12 treatments with four replications of 25 seeds. Each cryoprotectant (dimethyl sulfoxide and sucrose) was considered an independent experiment with two thawing methods (fast and slow).

The concentrations tested were $0 \%, 5 \%, 10 \%$, $15 \%, 20 \%$ and $25 \%$ (v:v) for dimethyl sulfoxide, and $0,0.25,0.5,0.75,1.0$ and $1.25 \mathrm{M}$ for sucrose. The seeds from each treatment were weighed and then immersed in the solution for $3 \mathrm{~h}$, except for the zero concentration treatment. After this period, they were removed and weighed again. The treatments at the lowest concentrations had an increase in water content, which was reduced to the same level they had before the immersion (by placing them in tulle bags in a desiccator containing silica gel), so that the seeds presented water content uniformity at the time of storage in liquid nitrogen.

The seeds were placed in foil/PET laminated sachets and immersed in liquid nitrogen for $120 \mathrm{~h}$. After the 
cryostorage period, the seeds were thawed using two different methods: slow thawing, in which the sachets containing the seeds were left on the laboratory bench at $25^{\circ} \mathrm{C}$ for $4 \mathrm{~h}$; and fast thawing, in which the sachets were subjected to warm water at $38^{\circ} \mathrm{C}$ for $30 \mathrm{~min}$. The seeds were then sowed to assess the effect of cryoprotectants and thawing methods.

Seedling emergence test was performed in a substrate consisting of sand and vermiculite at a ratio of 1:1 (v:v). Seeds were sowed at $1.0 \mathrm{~cm}$ depth and they were irrigated daily. The containers holding the substrate were placed on the laboratory benches. During the 45 days of evaluation, the lights were kept on $10 \mathrm{~h}$ per day, on average; the maximum daily temperatures ranged from 27.5 to $32.6{ }^{\circ} \mathrm{C}$, and the minimum from 22.3 to $29.1{ }^{\circ} \mathrm{C}$. The effect of reducing seeds water content was assessed through the variables: emergence percentage, speed index, length and seedlings fresh and dry matter mass.

Emergence percentage was calculated 45 days after sowing, when stability in the daily number of emerged plants occurred. The number of normal seedlings was counted, considering as emerged the ones that presented a shoot (hypocotyl, cotyledon, and primary leaf) that was $5.0 \mathrm{~mm}$ above the substrate. The emergence speed index was evaluated according to the equation proposed by Maguire (1962) using the daily emergence data.

The seedlings were withdrawn from the substrate. Their roots were washed in running water and slightly dried with paper. Then, seedling length and fresh and dry matter mass were evaluated. The seedling length was considered the distance between the first eophyll (primary leaf) and the end of the longest root, measured using a millimeter-graded ruler. The seedlings were placed in paper bags and kept in a forced air circulating oven at $65{ }^{\circ} \mathrm{C}$ to evaluate the dry matter mass. The masses were measured using an analytical balance with accuracy of $0.0001 \mathrm{~g}$.

The data were subjected to normality tests (ShapiroWilk) and homogeneity of variance (Bartlett). Then they were subjected to analysis of variance (F test) and polynomial regression using the statistical program $\mathrm{R}$ 2.15.2 (R Core Team, 2012).

\section{Results and discussion}

\section{Dimethyl sulfoxide use in cryopreservation}

There was no interaction between the different concentration of dimethyl sulfoxide as seed cryoprotectant and the two thawing methods (fast and slow). The emergence percentage, length, and dry matter mass of Genipa americana seedlings were not affected by the thawing methods (Table 1). The emergence speed index (ESI) and fresh matter mass (FMM) of seedlings from slowly thawed seeds were significantly higher $(32 \%$ and $25 \%$, respectively) than those from fast thawing seeds.

Table 1. Means of emergence percentage (E), emergence speed index (ESI), length (L), fresh matter mass (FMM), and dry matter mass (DMM) of seedlings from Genipa americana seeds treated with dimethyl sulfoxide under two thawing methods.

\begin{tabular}{cccccc}
\hline Thawing & E (\%) & ESI & L (cm) & $\begin{array}{c}\text { FMM } \\
(\mathbf{m g})\end{array}$ & $\begin{array}{c}\text { DMM } \\
(\mathbf{m g})\end{array}$ \\
\hline Slow $\left(25^{\circ} \mathrm{C}, 4 \mathrm{~h}\right)$ & $49.5 \mathrm{a}$ & $0.29 \mathrm{a}$ & $9.90 \mathrm{a}$ & $228.71 \mathrm{a}$ & $41.83 \mathrm{a}$ \\
Fast $\left(38^{\circ} \mathrm{C}, 30 \mathrm{~min}\right)$ & $54.8 \mathrm{a}$ & $0.22 \mathrm{~b}$ & $9.92 \mathrm{a}$ & $183.23 \mathrm{~b}$ & $39.29 \mathrm{a}$ \\
\hline $\mathrm{CV}(\%)$ & 26.45 & 38.31 & 20.71 & 25.49 & 20.89 \\
\hline
\end{tabular}

Means followed by the same letter in the column do not differ by Tukey's test at $5 \%$ probability.

The fast and slow thawing methods did not affect the seed potential of other species, as sunflower (Helianthus annuus L.) (Motta et al., 2014). However, for deep freezing stored pepper (Allium cepa L.), fast thawing in a heater at $37^{\circ} \mathrm{C}$ for 5 min yielded better results than slow thawing at $25^{\circ} \mathrm{C}$ for $2 \mathrm{~h}$ (Molina et al., 2006). According to these authors, in a low-temperature germplasm bank, not only the cryopreservation process but also the thawing method must be considered, since the faster the thawing of seeds, the better is the preservation of their physiological characteristics. This procedure may prevent the ice crystals within the cell, which would lead to destruction of the membrane and consequently cause cell death (Goldfarb et al., 2010).

Kholina \& Voronkova (2008) using 103 species and Voronkova \& Kholina (2010) using 11 species endemic to eastern Russia found that cryostored seeds subjected to slow thawing for $2 \mathrm{~h}$, under laboratory environmental conditions $\left(20-25^{\circ} \mathrm{C}\right)$, had no loss or physiological damage. Thymus lotocephalus seeds stored in liquid nitrogen were slowly thawed at room temperature for approximately $18 \mathrm{~h}$, and showed no signs of damage (Coelho et al., 2012). These studies, as well as the present study, demonstrate that seeds from several species can be slowly thawed without loss, contributing to the process by making the thawing simpler, without equipment for maintenance of constant high temperatures for the heater, which is required when using the fast thawing method. 
Regarding the seeds treated with various concentrations of dimethyl sulfoxide, all variables were entered into regression models, with the emergence percentage presenting a quadratic and the other a linear response model. G. americana seedling emergence percentages
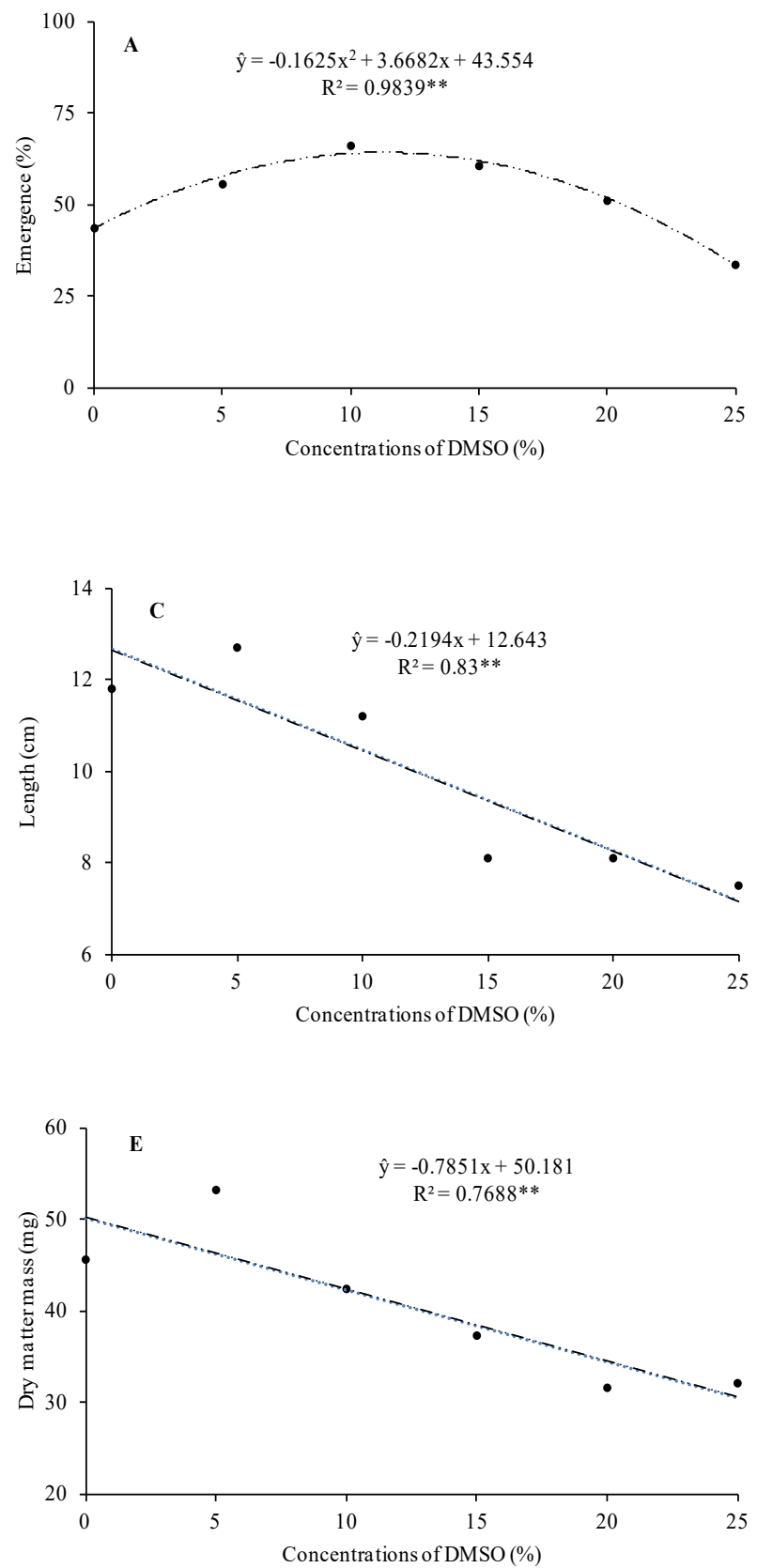

There was an increase of $46 \%$ in seedling emergence from 0 to $11.29 \%$ (estimated) concentration of dimethyl sulfoxide, proving the dimethyl sulfoxide effectiveness as a cryoprotectant. The maximum estimated value of had a maximum estimated value of $64.2 \%$, obtained at a concentration of $11.29 \%$ dimethyl sulfoxide (Figure 1a). ESI, length and seedlings fresh and dry matter mass presented decreasing values as the dimethyl sulfoxide concentration increased (Figures 1b, 1c, 1d, and 1e).
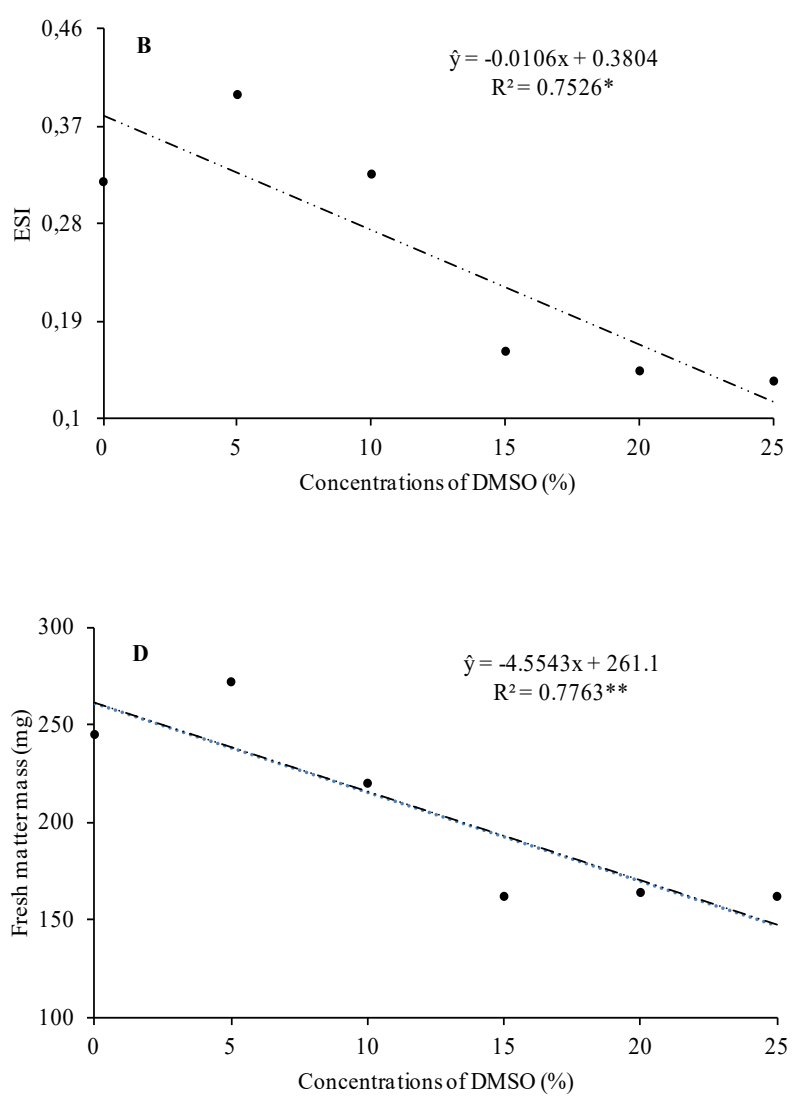

Figure 1. Emergence percentage (a), emergence speed index ESI (b), length (c), fresh matter mass (d) and dry matter mass (E) of Genipa americana seedlings depending on dimethyl sulfoxide (DMSO) concentrations.

$64.2 \%$ was obtained using $11.29 \%$ of dimethyl sulfoxide. This value is lower than the $84 \%$ that the seeds had before the deep freezing storage, although higher than the $44 \%$ obtained with frozen seeds without this 
treatment. This indicates that up to a concentration of $11.29 \%$ of dimethyl sulfoxide, there is seed protection, but above this value, seeds viability decrease, probably because of the cryoprotectant toxicity that may affect plant tissues and cells when used at higher concentrations (Sakai, 1995). Anchordoguy et al. (1987), studying the interaction of membrane phospholipids with cryoprotectants, found that dimethyl sulfoxide reduces liposome fusion that occurs during freezing when used at concentrations above $1 \mathrm{M}(7 \%)$, moreover thawing contributes to membrane deterioration and consequently to the reduction of seeds viability.
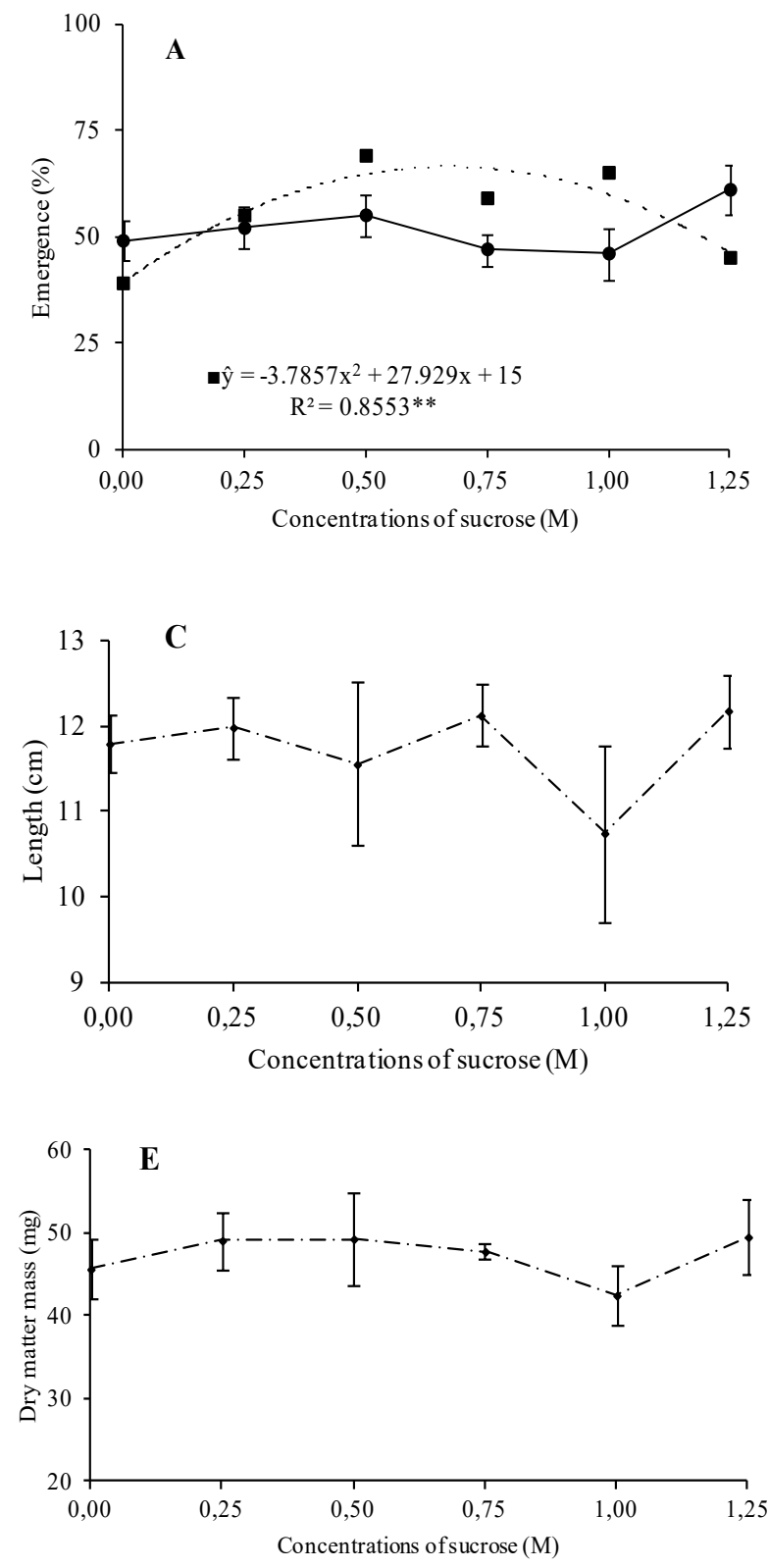

\section{Sucrose use in thawing deep frozen seeds}

There was interaction between the sucrose concentration factors and thawing methods for seedling emergence percentage and speed index.

Regarding the effects of sucrose concentrations on the seedling emergence percentage and speed index in each thawing method, the slowly thawed seeds did not fit any regression model, while under the fast method they fit the quadratic model (Figures $2 \mathrm{a}$ and $2 \mathrm{~b}$ ). The length, fresh matter mass and dry matter mass did not interact among the factors and did not fit any regression model.
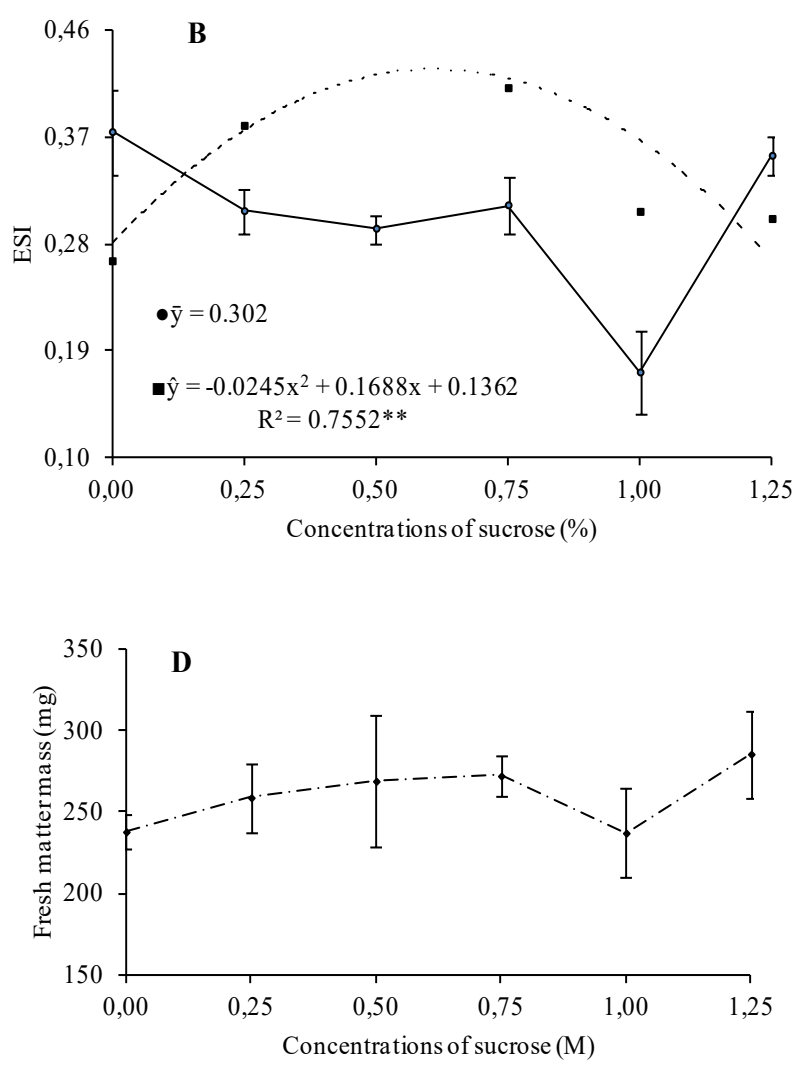

Figure 2. Emergence percentage (a), emergence speed index (b), length (c), fresh matter mass (d) and dry matter mass (E) of Genipa americana seedlings depending on sucrose concentrations. Slow thawing $=25^{\circ} \mathrm{C}, 4 \mathrm{~h}$; fast thawing $=38$ ${ }^{\circ} \mathrm{C}, 30$ min. 
The lowest percentage value for $G$. americana seedling emergence after slow thawing (46\%) was obtained at a sucrose concentration of $1 \mathrm{M}$, and the highest (61\%) was at $1.25 \mathrm{M}$, while after fast thawing, the maximum estimated value $(66.5 \%)$ was obtained for a concentration of $0.67 \mathrm{M}$. The emergence speed index of seedlings from slowly thawed seeds ranged from $0.17(1.0 \mathrm{M})$ to $0.37(0 \mathrm{M})$ with an average of 0.30 , while the seedlings from fast thawed seeds had a maximum estimated value of 0.42 at a sucrose concentration of $0.61 \mathrm{M}$. The seedling lengths ranged from $10.74 \mathrm{~cm}$ to $12.17 \mathrm{~cm}$; the fresh matter mass ranged from 237 $\mathrm{mg}$ to $286 \mathrm{mg}$; and the dry matter mass ranged from $42 \mathrm{mg}$ to $49 \mathrm{mg}$. The lower and higher values for these variables were found at concentrations of $1 \mathrm{M}$ and 1.25 $\mathrm{M}$, respectively (Figures 3c, 3d, and 3e). The seedling emergence percentage, length and fresh and dry matter mass from slowly thawed seeds presented the highest values when subjected to the cryoprotectant at a concentration of $1.25 \mathrm{M}$.

G. americana seeds presented different results for sucrose cryoprotectant depending on the thawing method; when slowly thawed, the best results were obtained at the maximum concentration $(1.25 \mathrm{M})$, but when fast thawed, the best results for emergence percentage and speed index were at concentrations of $0.67 \mathrm{M}$ and $0.61 \mathrm{M}$ of sucrose, respectively. These results indicate that the mechanisms involved in seed tolerance to cryostorage and its relations with cryoprotectants and thawing methods are quite complex, which increase the difficulty level to elaborate protocols for seeds cryostorage, even for a single species.

The use of slow thawing of cryostored seeds without losses has been observed frequently, as presented by Farias et al. (2006) in jatoba (Hymenaea courbaril L.), Rocha et al. (2009) in four cotton cultivars (Gossypium hirsutum L.), and by Kholina \& Voronkova (2012) in 12 native species from eastern Russia.

G. americana seeds treated with sucrose presented a maximum emergence percentage of $66.5 \%$, a value below the $84 \%$ before the cryostorage but above the $39 \%$ that they had without the sucrose treatment for storage in liquid nitrogen. The results indicate that the use of cryoprotectants in a sugar base contributes, in some manner, to the preservation of structures and functions important for seeds germination after cryostorage.
Another important aspect to note is that the cryoprotectants influence the germination process according to the thawing speed. It is not appropriate to compare the concentrations of dimethyl sulfoxide to those of sucrose because they are measured in different units. However, we can compare the means of each cryoprotectant within the thawing methods. This comparison revealed no significant differences for all variables studied (Figure 3).
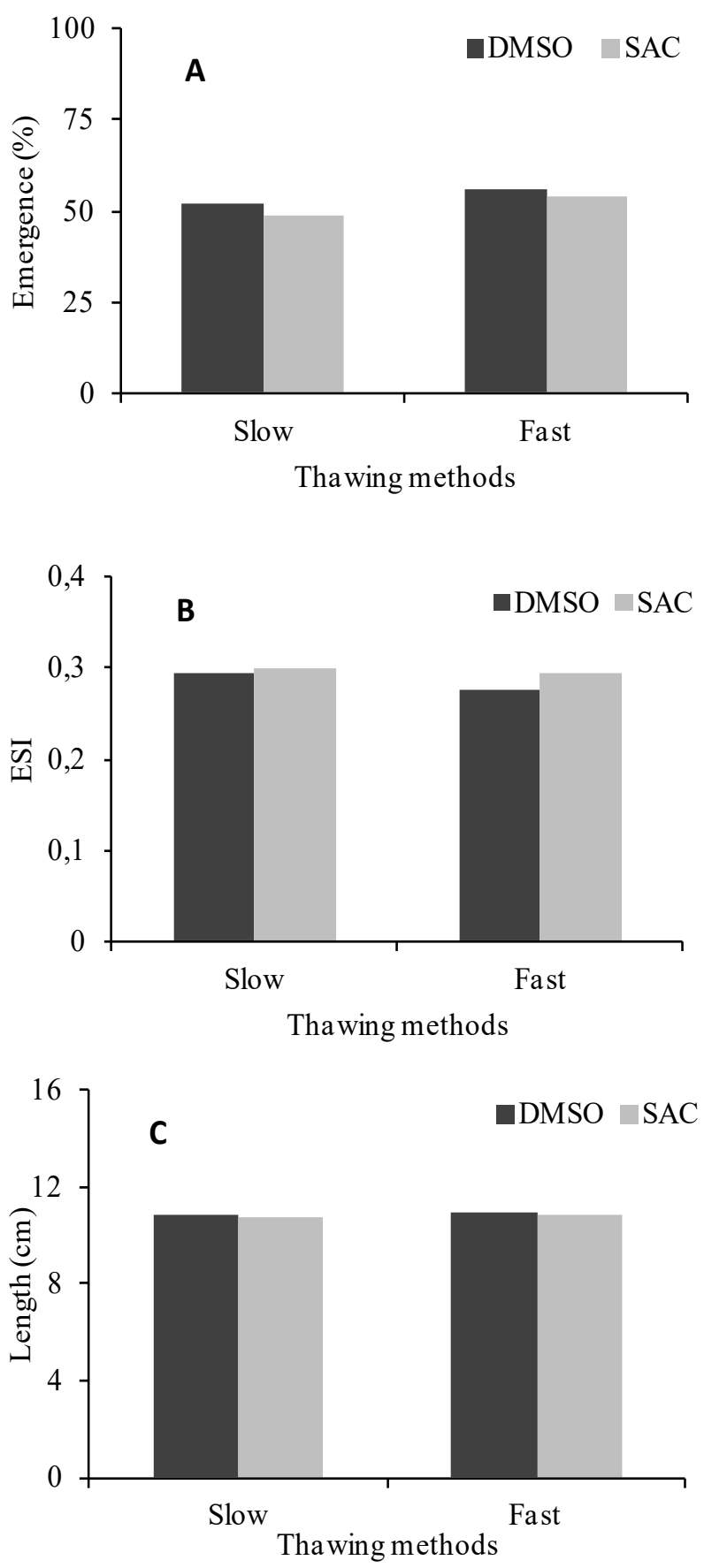

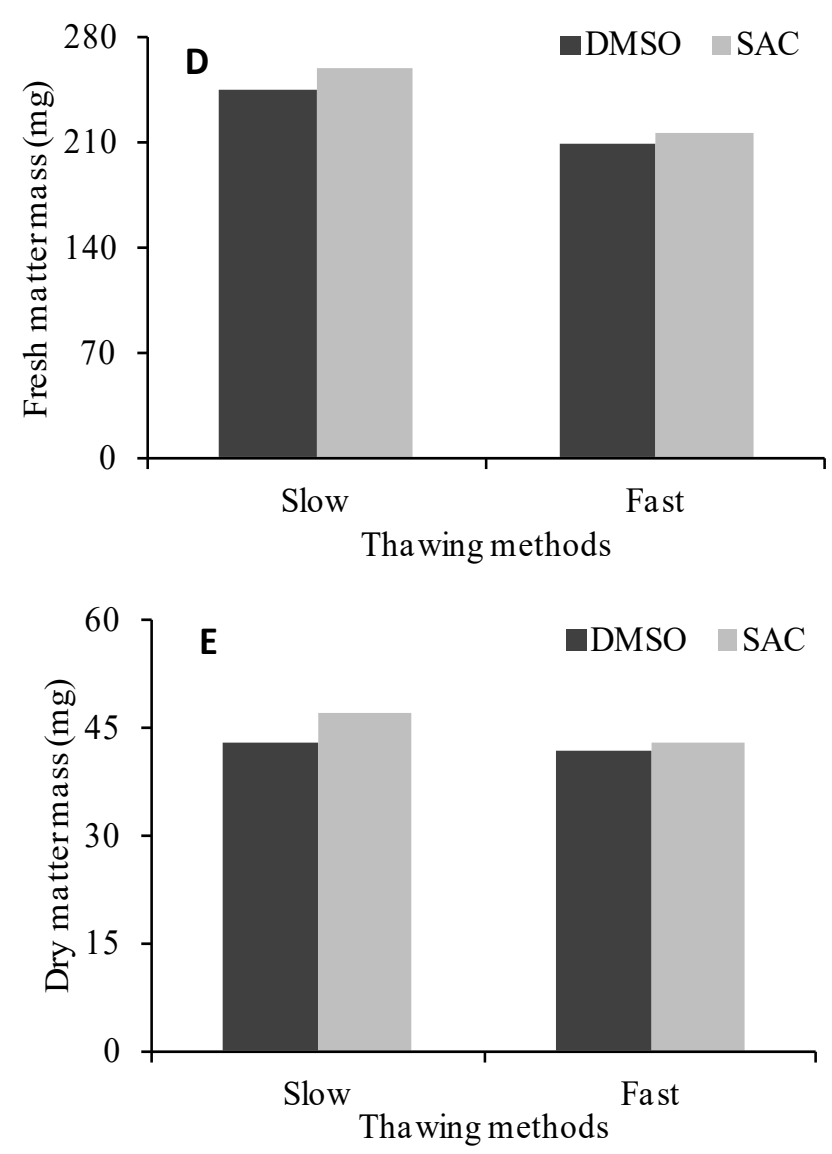

Figure 3. Effect of cryoprotectors dimethyl sulfoxide (DMSO) and sucrose (SAC) on emergence percentage (a), emergence speed index (b), length (c), fresh matter mass (d), and dry matter mass (e) of Genipa americana seedlings depending on thawing methods. Slow thawing $=25^{\circ} \mathrm{C}, 4 \mathrm{~h}$; fast thawing $=38{ }^{\circ} \mathrm{C}, 30 \mathrm{~min}$.

\section{Conclusions}

Dimethyl sulfoxide and sucrose can be successfully used as cryoprotectants for Genipa americana seeds. Thawing should be slow when treating seeds with dimethyl sulfoxide.

\section{Acknowledgments}

To Fundação de Amparo a Pesquisa do Estado de Mato GrossoFAPEMAT) for financial support.

\section{References}

Anchordoguy, T. J. et al. Modes of interaction of cryoprotectants with membrane phospholipids during freezing. Cryobiology, v. 24, n. 4, p. 324-331, 1987.
Benson, E. E. Cryopreservation theory. In: Reed, B. M. (Ed.). Plant cryopreservation: a practical guide. Corvalis: Springer, 2008. p. 15-32.

Brasil. Ministério da Agricultura, Pecuária e Abastecimento. Secretaria de Defesa Agropecuária. Regras para análise de sementes. Brasília, DF, 2009. 395 p.

Coelho, N. et al. Germination and cryopreservation tolerance of seeds from the rare aromatic species Thymus lotocephalus. Scientia Horticulturae, v. 145, n. 20, p. 84-86, 2012. DOI: 10.1016/j. scienta.2012.07.031.

Engelmann, F. In vitro conservation of tropical plant germplasm: a review. Euphytica, v. 57, n. 3, p. 227-243, 1991.

Farias, D. C. et al. Qualidade fisiológica de sementes de jatobá submetidas a diferentes temperaturas criogênicas. Revista Brasileira de Produtos Agroindustriais, v. 8, n. 1, p. 67-74, 2006.

Fonseca, A. G. et al. Qualidade fisiológica de sementes Pinus elliottii Engelm submetidas e diferentes métodos de armazenamento. Cerne, v. 18, n. 3, p. 457-463, 2012. DOI: 10.1590/S010477602012000300013 .

Gallo, C. M. Cultivo in vitro e criopreservação de Vasconcellea quercifolia A. St. Hil. 2015. 104 f. Tese (Doutorado em Agronomia) - Universidade Federal de Lavras, Lavras.

Goldfarb, M. et al. Armazenamento criogênico de sementes de pinhão manso (Jatropha curcas L.) Euphorbiaceae. Biotemas, v. 23, n. 1, p. 27-33, 2010. DOI: 10.5007/2175-7925.2010v23n1p27.

Kholina, A. B. \& Voronkova, N. M. Conserving the gene pool of far Eastern plants by means of seed cryopreservation. Biology Bulletin, v. 35, n. 3, p. 262-269, 2008. DOI: 10.1134/S1062359008030060.

Kholina, A. B. \& Voronkova, N. M. Seed cryopreservation of some medicinal legumes. Journal of Botany, v. 2012. Article 186891, 2012. DOI: $10.1155 / 2012 / 186891$.

Li, D. \& Pritchard, H. W. The science and economics of ex situ plant conservation. Trends in Plant Science, v. 14, n. 11, p. 614-621, 2009. DOI: $10.1016 /$ j.tplants.2009.09.005.

Maguire, J. D. Speeds of germination-aid selection and evaluation for seedling emergence and vigor. Crop Science, v. 2, n. 1, p. 176177, 1962.

Molina, T. F. et al. Crioconservação em sementes de cebola. Revista Brasileira de Sementes, v. 28, n. 3, p. 72-81, 2006. DOI: 10.1590/ S0101-31222006000300011.

Motta, L. B. et al. Cryostorage of sunflower seeds. Bioscience Journal, v. 30, n. 2, p. 312-319, 2014.

Padro, M. D. A. et al. Cryopreservation of white mulberry (Morus alba L.) by encapsulation-dehydration and vitrification. Plant Cell, Tissue and Organ Culture, v. 108, n. 1, p. 167-172, 2012. DOI: 10.1007/s11240-011-0017-5.

Pence, V. C. The possibilities and challenges of in vitro methods for plant conservation. Kew Bulletin, v. 65, n. 4, p. 539-547, 2010.

Pita, J. M. et al. Seed cryopreservation of seven Spanish native pine species. Silvae Genetica, v. 47, n. 4, p. 220-223, 1998.

$\mathrm{R}$ Core Team. R: A language and environment for statistical computing. Viena: R Foundation for Statistical Computing, 2012. 
Rocha, M. S. et al. Crioconservação de sementes de algodão. Revista Brasileira de Engenharia Agrícola e Ambiental, v. 13, n. 2, p. $312-$ 318, 2009. DOI: 10.1590/S1415-43662009000300013.

Sakai, A. Cryopreservation of germplasm of woody plants. In: Bajaj, Y. P. S. (Ed.). Biotechnology in agriculture and forestry. v. 32. Cryopreservation of plant germplasm I. Berlin: Springer-Verlag, 1995. p. 53-69.

Tao, D. \& Li, P. H. Classification of plan cell cryoprotectants. Journal of Theoretical Biology, v. 123, n. 1, p. 305-310, 1986. DOI: 10.1016/ S0022-5193(86)80245-4.
Tresena, L. T. et al. Qualidade físiológica da semente de ipê rosa (Tabebuia hepptahylla (Vellozo) Toledo) submetidas à crioconservação. Revista Brasileira de Produtos Agroindustriais, v. 11, n. 1, p. 87-92, 2009. DOI: 10.1590/S0104-77602012000300013.

Vasanth, K. \& Vivier, M. A. Improved cryopreservation procedure for long term storage of synchronized culture of grapevine. Biologia Plantarum, v. 55, n. 2, p. 365-369, 2011.

Voronkova, N. M. \& Kholina, A. B. Conservation of endemic species from the Russian far east using seed cryopreservation. Biology Bulletin, v. 37, n. 5, p. 496-501, 2010. DOI: 10.1134/ S1062359010050092. 